\title{
Genetic diversity in the growth of white jabon (Neolamarckia cadamba) provenance-progeny test: Comparing study in the nursery and field
}

\author{
DEDE J. SUDRAJAT ${ }^{1, \boldsymbol{v}}$, YULIANTI ${ }^{1}$, DANU ${ }^{1}$, EVAYUSVITA RUSTAM ${ }^{1}$, ICHSAN SUWANDHI ${ }^{2}$ \\ ${ }^{1}$ Forest Tree Seed Technology Research and Development Center. Jl. Pakuan Ciheuleut, PO Box 105, Bogor 16143, West Java, Indonesia. \\ Tel./fax.: +62-251-8327768, "email: djsudrajatbtp@yahoo.com \\ ${ }^{2}$ Department of Forestry Engineering, School of Life Sciences and Technology, Institut Teknologi Bandung. Jl. Raya Bandung-Sumedang Km 20.75 , \\ Jatinangor, Sumedang 45363, West Java, Indonesia
}

Manuscript received: 2 April 2019. Revision accepted: 17 April 2019

\begin{abstract}
Sudrajat DJ, Yulianti, Danu, Rustam E, Suwandhi I. 2019. Genetic diversity in the growth of white jabon (Neolamarckia cadamba) provenance-progeny test: Comparing study in the nursery and field. Biodiversitas 20:1325-1332. Results of the provenanceprogeny test in seedling and field test of white jabon (Neolamarckia cadamba) at Parung Panjang, Bogor District, West Java Province, Indonesia are reported and discussed. Twelve provenances representing 105 families were tested in nursery and field using randomized complete block design. Seedling height, root collar diameter, sturdiness quotient, shoot dry weight, root dry weight and shoot-root ratio was measured at four months, while as the growth assessment was carried out on survival, height and stem diameter at the age of 2 and 4 years. The result showed that genetic variation was found to be higher among families within provenances than the variation among provenances for all parameters indicating the family effect had the highest contribution on the growth and survival. Based on family and provenance mean, most of the seedling parameters were significantly correlated with the others, but most of seedling parameters were not significantly correlated with plant growth at 2 and 4 years. The longitudinal cline was significantly correlated with shoot dry weight, root dry weight, and shoot-root ratio indicated that the white jabon seeding parameters in natural populations may have greater in humid (higher precipitation) than in drier locations. This was likely to suggest that the family or provenance selections based on seedling growth in the nursery may not be very effective because heritability of most growth variables is likely to be low.
\end{abstract}

Keywords: Correlation, family, seedling, survival, white jabon

\section{INTRODUCTION}

Growth diversity in geographic and genetic of trees is important to recommend appropriate seed sources for establishment forest plantation and land rehabilitation, especially for reforestation in a changing climate (Jacobs et al. 2015; Weber et al. 2018). Field tests in long term period to investigate geographic and genetic variation in tree growth have been used widely (Morgenstern 1996). The tests require high cost in establishment and maintenance and as an alternative, some tree improvement activities use short term nursery tests (Cuni-Sanchez et al. 2011; Korbo et al. 2012; Ky-Dembele et al. 2014; Bouda et al. 2015; Weber et al. 2015; Bezzalla et al. 2017; Bayala et al. 2017). However, the studies are needed to find the conclusions the effectivity of selection in seedling stage. This study investigated geographical and genetic diversity in growth traits and the correlation between seedling growth in nursery and field test of white jabon (Neolamarckia cadamba (Roxb.) Miq., family Rubiaceae) from the Indonesia eco-zone.

White jabon is an Indonesia native fast-growing tree species, which can be used for many purposes. The timber can be used for pulp, plywood and light construction (Soerianegara and Lemmens 1993), and various parts of the plant have bioactive compounds, including antibacterial, antioxidant, hypolipidemic, hypoglycemic, and antimicrobial properties (Acharyya et al. 2011; Mishra and
Siddique 2011). The species distributes widely in the tropical evergreen lowland rain forests of Asia, extending through India, Sri Lanka, Nepal, Burma, Malaysia, Indonesia, Philippines and New Guinea (Lamprecht 1989). In Indonesia, this species can be found in almost all islands and plays an important role in commercial and traditional farming systems (Kallio et al. 2011; Irawan and Purwanto 2014).

Characteristics of seedling in the nursery such as height, root collar diameter, shoot weight, root weight, root/shoot weight ratio, and root growth potential can influence early growth in the field (Villar-Salvador et al. 2004; Zida et al. 2008; Trubat et al. 2011; Budiman et al. 2015). For white jabon, root collar diameter, shoot height, seedling biomass and sturdiness quotient in the nursery is useful as a predictor the seedling survival and early growth in the field. The seedling height in the nursery was significantly correlated with the seedling height in the field test (Budiman et al. 2015). Assuming that shoot growth is heritable and contributed to fitness in natural populations, the hypothesis that seedling height positively correlated with the tree height in the field, so the selection of white jabon seedlings in the nursery may be potential to be carried out in tree improvement programs.

Provenance/progeny tests of white jabon from Indonesia were established in the nursery and field at Parung Panjang, Bogor, West Java using 105 families from 12 provenances. The genetic diversity of the planting 
material used in the provenance-progeny test based on AFLP markers was relatively high (Sudrajat et al. 2015), and based on seedling morphological traits, genotypic variance and genotypic coefficient of variance were found to be higher than corresponding environment variance and environment coefficient of variance (Sudrajat 2016). Early results from the field test at one year indicated that significant differences among the provenances and families within provenances were observed for height and collar diameter with moderate heritability (Sudrajat et al. 2016). Results of the correlation of the nursery test and other results from the field test have not been reported. The purposes of the research are to identify (i) genetic variation in growth parameters at seedling stage in the nursery and the field test ( 2 and 4 years); (ii) correlations of seedling growth in nursery with tree growth in the field test; and (iii) correlations among seedling growth in the nursery, tree growth in the field test, and the geo-climate condition of the provenances. Simple correlations were measured based on provenance and family means.

\section{MATERIALS AND METHODS}

\section{Materials}

Open-pollinated seeds of 105 families of white jabon were collected from 12 natural population of Indonesia distributed in Java, Sumatra, Kalimantan, Sulawesi, Sumbawa and Papua islands (Table 1, Figure 1). The sampled trees were selected based on phenotypically average or above average concerning stem diameter (breast height diameter) and total height compared with around trees in the population. The distance among mother trees within the population was kept at a minimum $100 \mathrm{~m}$ distance to minimize relatedness between seed lots. Seeds were collected by climbing the tree samples. Every seed lot was separated for each sample tree and was given the information about locations and number of samples. The information was kept on until seed processing, nursery stage, and establishment the provenance-progeny test.

Table 1. Provenance detail of white jabon and their geo-climate conditions

\begin{tabular}{|c|c|c|c|c|c|c|}
\hline $\begin{array}{c}\text { Provenance } \\
\text { code }\end{array}$ & Locality & Lat. & Lon. & $\begin{array}{l}\text { Alt. } \\
\text { (m asl) }\end{array}$ & $\begin{array}{l}\text { Climate type } \\
\text { (Schmidt and } \\
\text { Fergusson) }\end{array}$ & $\begin{array}{c}\text { Number of } \\
\text { families } \\
\text { (plus tree) }\end{array}$ \\
\hline RPS & Rimbo Panti Nature Reverse, Pasaman, West Sumatra & $00^{\circ} 19^{\prime} \mathrm{N}$ & $100^{\circ} 05^{\prime} \mathrm{E}$ & 294 & $\mathrm{~A}$ & 2 \\
\hline KRS & Kampar, Riau, Sumatra & $00^{\circ} 18^{\prime} \mathrm{N}$ & $100^{\circ} 57^{\prime} \mathrm{E}$ & 50 & A & 14 \\
\hline $\mathrm{OKS}$ & Ogan Komering Ilir, South Sumatra & $03^{\circ} 12^{\prime} \mathrm{S}$ & $104^{\circ} 51^{\prime} \mathrm{E}$ & 23 & $\mathrm{~B}$ & 11 \\
\hline GSJ & Garut Selatan, West Java & $07^{\circ} 26^{\prime} \mathrm{S}$ & $107^{\circ} 42^{\prime} \mathrm{E}$ & 628 & $\mathrm{~B}$ & 8 \\
\hline NKJ & Nusa Kambangan Nature Reverse, Central Java & $07^{\circ} 43^{\prime} \mathrm{S}$ & $108^{\circ} 55^{\prime} \mathrm{E}$ & 40 & $\mathrm{D}$ & 7 \\
\hline APJ & Alas Purwo National Park, East Java & $08^{\circ} 38^{\prime} \mathrm{S}$ & $114^{\circ} 21^{\prime} \mathrm{E}$ & 33 & D-E & 11 \\
\hline BLB & Batu Licin, Tanah Bumbu, South Kalimantan & $03^{\circ} 19^{\prime} \mathrm{S}$ & $115^{\circ} 41^{\prime} \mathrm{E}$ & 47 & B & 4 \\
\hline KTB & Kapuas Tengah, Central Kalimantan & $01^{\circ} 00^{\prime} \mathrm{S}$ & $114^{\circ} 28^{\prime} \mathrm{E}$ & 147 & A & 2 \\
\hline PGC & Parangloe, Gowa, South Sulawesi & $05^{\circ} 14^{\prime} \mathrm{S}$ & $119^{\circ} 35^{\prime} \mathrm{E}$ & 119 & $\mathrm{C}$ & 15 \\
\hline $\mathrm{PKC}$ & Pomalaa, Kolaka, Southeast Sulawesi & $04^{\circ} 03^{\prime} \mathrm{S}$ & $121^{\circ} 39^{\prime} \mathrm{E}$ & 210 & $\mathrm{C}$ & 22 \\
\hline BHS & Batu Hijau, Sumbawa, West Nusa Tenggara & $08^{\circ} 58^{\prime} \mathrm{S}$ & $116^{\circ} 48^{\prime} \mathrm{E}$ & 53 & $\mathrm{D}$ & 8 \\
\hline KKP & Kuala Kencana, Mimika, Papua & $04^{\circ} 24^{\prime} \mathrm{S}$ & $136^{\circ} 52^{\prime} \mathrm{E}$ & 107 & A & 1 \\
\hline
\end{tabular}

Note: $\mathrm{N}=$ Nort, $\mathrm{S}=$ South, $\mathrm{E}=$ East, $\mathrm{m}$ asl = meter above sea level

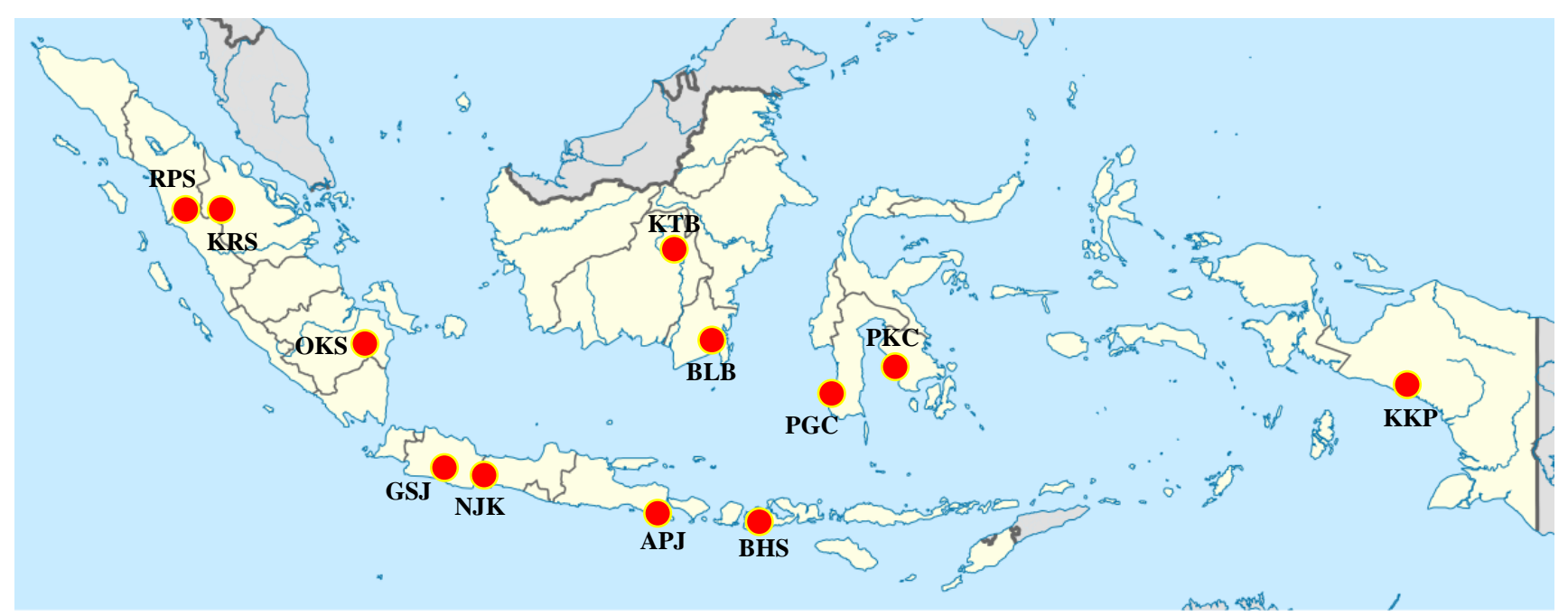

Figure 1. Geographic distribution of 12 populations of white jabon in Indonesia. See Table 1 for provenance code and location 


\section{Seedling preparation and experimental design in nursery}

The nursery was conducted at the Nagrak Research Station, Forest Tree Seed Technology Research and Development Center, Bogor, West Java, Indonesia (106 $511^{\prime} 27^{\prime \prime}$ E, 06 $6^{\circ} 74^{\prime \prime}$ S). Mean annual precipitation and temperature at the research station were $2500 \mathrm{~mm}$ and $26^{\circ} \mathrm{C}$. Seeds were sown in germination box using the mixed media of sand, compost, and charcoal (5: 3: 1, by volume). Prior to sowing the media was treated by steamsterilization to avoid any chance of fungus infection to newly germinated seedlings. Germination boxes were irrigated with fine sprayer to keep them wet and maintained in greenhouse. Two months after sowing, normal seedlings with four leaves were transplanted on polythene bags (10 $\mathrm{cm}$ in diameter and $15 \mathrm{~cm}$ in height), contained the mixed media of topsoil, sand, and compost in ratio of 2: 1: 1 (volume) and set up in nursery. Randomized complete block design was used to test the seedling growth from 105 families and 4 replications. Each replication consisted of 16 seedlings (4 seedlings $\mathrm{x} 4$ seedlings). Measurement of seedling parameters on each replication was carried out on the middle position of seedling lot (3 seedlings $\mathrm{x} 3$ seedlings) to avoid side effect. Seedling growth parameters (height, root collar diameter, sturdiness quotient, shoot dry weight, root dry weight and shoot-root ratio) was measured at the end of the nursery test (4 months after transplanting). For dry weight measurements, three seedlings were randomly selected, harvested and divided into roots, stems, and leaves. Roots, stems, and leaves were dried separately in a drying oven at $70^{\circ} \mathrm{C}$ for $48 \mathrm{~h}$ and weighed to \pm 0.0001 g. Leaves and stems were aggregated and are subsequently referred to as shoot dry weight and roots are referred to as root dry weight. Shoot root ratio (SRR) was calculated using the following formula Sudrajat (2016): SRR = shoot dry weight / root dry weight.

\section{Field test experimental design}

The experiment was set up at Parung Panjang, Bogor, West Java, Indonesia (06²0’42” S, 10606’15” E, $52 \mathrm{~m}$ asl). Mean annual precipitation and temperature are 2440 $\mathrm{mm}$ and $28^{\circ} \mathrm{C}$. The soil has low levels of N, P, K and Corganic with $\mathrm{pH} 4.2$ (Sudrajat et al. 2016). The site was selected to represent the common site condition of forest plantation industries that generally established in podzolic soil associated with low $\mathrm{pH}$ and low soil nutrients. Fourmonth-old seedlings were carried from Nagrak nursery to field experimental site at Parung Panjang. The seedlings were planted at the fields in February 2013 (pit size 40 x 40 $\mathrm{x} 40 \mathrm{~cm}$ ) with $3 \mathrm{~kg}$ manure per seedling as a basic fertilizer. The spacing was $3 \mathrm{~m} \times 3 \mathrm{~m}$ in a randomized complete block design (RCBD) with 5 replications of 4tree row plots. Within three months after planting $100 \mathrm{~g}$ of NPK fertilizer (15: 15: 15) was applied to each plant. Weed competition was kept to a minimum by manual weeding. All the trees in each plot constituted the measuring unit in all the replications. The growth assessment was carried out on seedling survival, total height and stem diameter at the age of 2 and 4 years after planting.

\section{Data analysis}

The SAS 9.1.3 Portable was used for all analyses, and the significance level was $\alpha \leq 0.05$ for all tests. The data were analyzed to determine the provenance and family effects using two-way analysis of variance (ANOVA). Before performing the analysis, data were examined for conformity to normal distribution and homogeneity of the variance assumptions. ANOVA for all parameters was conducted using the following statistical model (Falconer and Mackay 1996; Sebbenn et al. 2003):

$$
\mathrm{Y} i j k l=\mu+\mathrm{R} i+\mathrm{P} j+\mathrm{F}(\mathrm{P}) k(j)+\mathrm{RP} i j+\mathrm{RF}(\mathrm{P}) i k(j)+\mathrm{E} l(i j k)
$$

Where: Yijkm is the measurement on the $l^{\text {th }}$ individual of the $k^{\text {th }}$ family from the $j^{\text {th }}$ provenance in the $i^{\text {th }}$ replication; $\mu$ is the overall mean; $\mathrm{R} i$ is the effect of $i^{\text {th }}$ replication $(i=1,2$, $3, \ldots, \mathrm{n}) ; \mathrm{P} j$ is the effect of $j^{\text {th }}$ provenance $(j=1,2,3, \ldots, \mathrm{n}) ; \mathrm{F}$ $(\mathrm{P}) k(j)$ is the effect of $k^{\text {th }}$ family in $j^{\text {th }}$ provenance $(k=1,2$, $3, \ldots, \mathrm{n}) ; \mathrm{RP} i j$ is the interaction effect between $i^{\text {th }}$ replications and $j^{\text {th }}$ provenance; $\mathrm{RF}(\mathrm{P}) i k(j)$ is the interaction between $i^{\text {th }}$ replications and $k^{\text {th }}$ family within $j^{\text {th }}$ provenance; $\mathrm{E} l(i j k)$ is the residual.

The SAS PROC GLM was used to obtain the coefficients of the expected mean squares. The components of variance were calculated using VARCOMP PROC from SAS statistical program (SAS, 1999).

In the analyses of variance, calculation was focused in the variation due to families and provenances. Components of variance and relative contribution were calculated the total variance for random effects in the model (i.e., sum of variance components) and the percent of the total variance (referred to below as percent variance) due to provenances and families nested within provenances. Pearson correlation coefficients were used to assess linear relationships among variables and provenance's geoclimate conditions. Correlations were computed using family and provenance means. In addition, correlations were computed among growth variables of all seedlings in the nursery and separately for seedlings in each age ( 2 and 4 years after planting) in the field. The latitude, longitude, altitude, precipitation (mean annual rainfall), and mean annual temperature of families were based on the recorded values at the location of the provenances. Mean latitude and longitude of provenances were calculated from the values of all mother trees in the provenance.

\section{RESULTS AND DISCUSSIONS}

\section{Growth variation in the nursery and in the field}

All growth parameters in the nursery and field test were affected significantly by provenances and families nested in provenances, except for stem diameter of among provenances at 4 years after planting (Table 2). Growth performances in the nursery and field test varied significantly due to families and provenances. The provenance means and standard deviation of seedling and tree height, respectively, were $30.47 \mathrm{~cm}$ and $9.44 \mathrm{~cm}$ at nursery, $4.70 \mathrm{~m}$ and $0.54 \mathrm{~m}$ at 2 years, and $7.95 \mathrm{~m}$ and 2.25 
$\mathrm{m}$ at 4 years, while for seedling/tree diameter, the provenance mean and standard deviation were $4.56 \mathrm{~mm}$ and $0.85 \mathrm{~mm}$ at nursery, $7.50 \mathrm{~cm}$ and $0.74 \mathrm{~cm}$ at 2 years and $10.12 \mathrm{~cm}$ and $3.38 \mathrm{~cm}$ at 4 years, respectively. The tree height at 4 years was ranged from 5.1 to $10.2 \mathrm{~m}$ for provenances and 2.6 to $15.0 \mathrm{~m}$ for families, while for the diameter, the range was from 6.7 to $15.1 \mathrm{~cm}$ for provenances and 1.1 to $15.0 \mathrm{~cm}$ for families (Table 3). The significant differences for most of the seedling morphological and plant growth characteristics indicated the variability among provenances and families within provenances.

Coefficient variation (CV) was greater for families than for provenances. In nursery level, CV was largest for collar diameter, root dry weight and shoot-root ratio $(27.78 \%$, $22.72 \%$ and $21.02 \%$, respectively), intermediate and low $\mathrm{CV}$ were for shoot dry weight, seedling height and sturdiness quotient. $\mathrm{CV}$ in the height due to provenance was $17.98 \%$ at nursery, but it decreased to $7.30 \%$ at 2 years and $5.01 \%$ at 4 years in the field. The trend was similar to the seedling diameter that the $\mathrm{CV}$ decreased from $27.78 \%$ at nursery stage to $6.32 \%$ at 2 years and $1.58 \%$ at 4 years (Table 3). CVs displayed a decreasing trend with age for growth characters also was reported by Mihai and Mirancea (2016) on Abies alba and Weber et al. (2018) on Balanites aegyptiaca

At the nursery, the Kuala Kencana provenance attained a maximum height followed by Garut, Pomalaa, Gowa and Nusa Kambangan provenances. The Kuala Kencana provenance also recorded the highest collar diameter followed by Kampar, Pomalaa, Nusa Kambangan and Alas Purwo provenances. Generally, based on height, collar diameter and dry weight of seedling, the Kuala Kencana provenance had the superior growth, followed by Kampar and Garut provenance, while the Batu Licin and Kapuas provenances were recorded as the inferior provenances.
The similar trend was occurred at 2 years old at the field, the Kuala Kencana provenance had the highest height and stem diameter, followed by Alas Purwo provenance.

The growth ranking slightly changed at 4 years, the highest tree height was Alas Purwo provenance followed by Garut, Batu Hijau, and OKI provenances, but for stem diameter, Kuala Kencana provenance still performed the best performance followed by Gowa, OKI and Batu Hijau provenances. Field survival was recorded maximum in Batu Hijau provenance, followed by Rimbo Panti and Pomalaa provenances at 2 years. The Batu Hijau provenance also had the highest survival at 4 years followed by Pomalaa and Garut Provenances (Table 4). The best height provenance (Alas Purwo) at 4 years presented approximately $18.75 \%$ faster than the slowest growth provenance (Rimbo Panti), while as for root collar diameter, the Kuala Kencana provenance was higher and presented about $28.21 \%$ higher growth than the least growth provenance (Kapuas). Overall at 4 years, Alas Purwo, Kuala Kencana, OKI and Batu Hijau provenances were the 5 top provenances for height and stem diameter growth. The location of this trial could be categorized as a marginal site for white jabon, and according to Wahyudi (2012), the economical rotation could be reached at 13 years. The next evaluation would be carried out at 5 and 6 years (half rotation age) predicted that the growth would be more stable (Yang et al. 2013).

On the other hand, a component of variance among families within provenances $\left(\sigma_{\mathrm{F}}^{2} \mathrm{P}\right)$ was higher than a component of variance among provenances $\left(\sigma_{\mathrm{P}}^{2}\right)$ at all parameters (Table 4). The high degree of variation within populations as compared with the inter-population variation also was reported by Longauer (2001) and Mihai and Mirancea (2016) on Abies alba, indicating the family effect had the highest contribution on the growth and survival variation.

Table 2. Mean square for seedling morphological parameters in the nursery, tree height and diameter at 2 and 4 years old in the field of white jabon in Bogor, West Java, Indonesia

\begin{tabular}{|c|c|c|c|c|c|c|c|c|c|c|}
\hline \multirow[b]{3}{*}{$\begin{array}{l}\text { Source of } \\
\text { variation }\end{array}$} & \multirow{2}{*}{\multicolumn{6}{|c|}{ Mean square in the nursery }} & \multicolumn{4}{|c|}{$\begin{array}{c}\text { Mean square } \\
\end{array}$} \\
\hline & & & & & & & \multicolumn{2}{|c|}{2 years after planting } & \multicolumn{2}{|c|}{4 years after planting } \\
\hline & $\begin{array}{c}\text { Seedling } \\
\text { height }(\mathrm{m})\end{array}$ & $\begin{array}{c}\text { Collar } \\
\text { diameter } \\
(\mathrm{cm})\end{array}$ & $\begin{array}{c}\text { Sturdiness } \\
\text { quotient }\end{array}$ & $\begin{array}{l}\text { Shoot dry } \\
\text { weight (g) }\end{array}$ & $\begin{array}{l}\text { Root dry } \\
\text { weight } \\
\text { (g) }\end{array}$ & $\begin{array}{c}\text { Shoot } \\
\text { root } \\
\text { ratio }\end{array}$ & $\begin{array}{l}\text { Tree height } \\
\text { (m) }\end{array}$ & $\begin{array}{c}\text { Tree } \\
\text { diameter } \\
(\mathrm{cm})\end{array}$ & $\begin{array}{c}\text { Tree } \\
\text { height } \\
\text { (m) }\end{array}$ & $\begin{array}{c}\text { Tree } \\
\text { diameter } \\
(\mathbf{c m})\end{array}$ \\
\hline $\mathrm{R}$ & $\begin{array}{c}213.819 \\
*\end{array}$ & $\begin{array}{c}7.150 \\
\mathrm{~ns}\end{array}$ & $\begin{array}{c}26.051 \\
* *\end{array}$ & $\begin{array}{c}4.194 \\
* *\end{array}$ & $\begin{array}{c}0.255 \\
* *\end{array}$ & $\begin{array}{c}4.216 \\
\mathrm{~ns}\end{array}$ & $\begin{array}{c}323.240 \\
* *\end{array}$ & $\begin{array}{c}0.048 \\
* *\end{array}$ & $\begin{array}{c}299.368 \\
* *\end{array}$ & $\begin{array}{c}435.469 \\
* *\end{array}$ \\
\hline $\mathrm{P}$ & $\begin{array}{c}9439.190 \\
* *\end{array}$ & $\begin{array}{c}50.027 \\
* *\end{array}$ & $\begin{array}{c}350.909 \\
* *\end{array}$ & $\begin{array}{c}15.436 \\
* *\end{array}$ & $\begin{array}{c}1.431 \\
* *\end{array}$ & $\begin{array}{c}11.437 \\
* *\end{array}$ & $\begin{array}{c}59.920 \\
* *\end{array}$ & $\begin{array}{c}0.009 \\
*\end{array}$ & $\begin{array}{c}8.495 \\
* *\end{array}$ & $\begin{array}{c}14.442 \\
\mathrm{~ns}\end{array}$ \\
\hline $\mathrm{F}(\mathrm{P})$ & $\begin{array}{c}2475.025 \\
* *\end{array}$ & $\begin{array}{c}25.704 \\
* *\end{array}$ & $\begin{array}{c}78.848 \\
* *\end{array}$ & $\begin{array}{c}5.473 \\
* *\end{array}$ & $\begin{array}{c}0.607 \\
* *\end{array}$ & $\begin{array}{c}6.014 \\
* *\end{array}$ & $\begin{array}{c}338.270 \\
* *\end{array}$ & $\begin{array}{c}0.076 \\
* *\end{array}$ & $\begin{array}{c}7.418 \\
* *\end{array}$ & $\begin{array}{c}15.028 \\
* *\end{array}$ \\
\hline $\mathrm{R} * \mathrm{P}$ & $\begin{array}{c}53.595 \\
*\end{array}$ & $\begin{array}{c}1.616 \\
\mathrm{~ns}\end{array}$ & $\begin{array}{c}2.703 \\
\mathrm{~ns}\end{array}$ & $\begin{array}{c}0.860 \\
* *\end{array}$ & $\begin{array}{c}0.258 \\
* *\end{array}$ & $\begin{array}{c}2.188 \\
* *\end{array}$ & $\begin{array}{c}184.420 \\
* *\end{array}$ & $\begin{array}{c}0.034 \\
* *\end{array}$ & $\begin{array}{c}8.148 \\
* *\end{array}$ & $\begin{array}{c}14.227 \\
*\end{array}$ \\
\hline $\mathrm{R} * \mathrm{~F}(\mathrm{P})$ & $\begin{array}{c}56.007 \\
* *\end{array}$ & $\begin{array}{c}2.045 \\
\text { ns }\end{array}$ & $\begin{array}{c}2.237 \\
\mathrm{~ns}\end{array}$ & $\begin{array}{c}0.726 \\
* *\end{array}$ & $\begin{array}{c}0.204 \\
* *\end{array}$ & $\begin{array}{c}2.337 \\
* *\end{array}$ & $\begin{array}{c}123.350 \\
* *\end{array}$ & $\begin{array}{c}0.218 \\
* *\end{array}$ & $\begin{array}{c}7.231 \\
* *\end{array}$ & $\begin{array}{c}13.708 \\
* *\end{array}$ \\
\hline Error & 30.331 & 1.624 & 1.727 & 0.119 & 0.015 & 0.640 & 921.330 & 0.268 & 1.991 & 8.303 \\
\hline
\end{tabular}

Note: R: replication (block), P: provenance, F: famili, **: significant at $\mathrm{P}<0.01$, *: significant at $\mathrm{P}<0.05$, ns: no significant 
Table 3. Growth performance of various provenances of white jabon in the nursery, 2 and 4 years in the field (number in parentheses are ranks)

\begin{tabular}{|c|c|c|c|c|c|c|c|c|c|c|c|c|}
\hline \multirow[b]{2}{*}{ Provenance } & \multicolumn{6}{|c|}{ Nursery } & \multicolumn{3}{|c|}{2 years after planting } & \multicolumn{3}{|c|}{4 years after planting } \\
\hline & $\begin{array}{c}\text { Seedling } \\
\text { height } \\
(\mathrm{m})\end{array}$ & $\begin{array}{c}\text { Collar } \\
\text { diameter } \\
(\mathrm{cm})\end{array}$ & $\begin{array}{c}\text { Sturdiness } \\
\text { quotient }\end{array}$ & $\begin{array}{l}\text { Shoot dry } \\
\text { weight }(\mathrm{g})\end{array}$ & $\begin{array}{c}\text { Root dry } \\
\text { weight (g) }\end{array}$ & $\begin{array}{c}\text { Shoot } \\
\text { root } \\
\text { ratio }\end{array}$ & $\begin{array}{c}\text { Tree } \\
\text { height } \\
(\mathrm{m})\end{array}$ & $\begin{array}{c}\text { Tree } \\
\text { diameter } \\
(\mathrm{cm})\end{array}$ & $\begin{array}{c}\text { Survival } \\
(\%)\end{array}$ & $\begin{array}{c}\text { Tree } \\
\text { height } \\
(\mathrm{m})\end{array}$ & $\begin{array}{c}\text { Tree } \\
\text { diameter } \\
(\mathbf{c m})\end{array}$ & $\begin{array}{c}\text { Survival } \\
(\%)\end{array}$ \\
\hline RPS & $18.0(10)$ & $4.58(7)$ & $3.54(12)$ & $2.29(4)$ & $0.97(1)$ & $2.18(12)$ & $4.19(11)$ & $7.1(10)$ & $72.5(2)$ & $7.09(12)$ & $9.67(9)$ & $51.1(8)$ \\
\hline KRS & $32.4(5)$ & $5.09(2)$ & $6.59(7)$ & $2.55(2)$ & $0.71(3)$ & $3.16(5)$ & $4.69(8)$ & $7.3(9)$ & $54.9(7)$ & $7.92(6)$ & $9.91(8)$ & $54.0(5)$ \\
\hline $\mathrm{OKS}$ & $33.8(4)$ & $4.49(8)$ & $7.47(2)$ & $1.62(9)$ & $0.42(11)$ & $4.18(3)$ & $4.65(9)$ & $7.5(8)$ & $55.8(5)$ & $8.06(4)$ & $10.28(3)$ & $52.7(7)$ \\
\hline GSJ & $34.9(2)$ & $4.63(6)$ & $7.75(1)$ & $2.35(3)$ & $0.60(5)$ & $4.22(2)$ & $4.96(4)$ & $7.6(5)$ & $54.0(9)$ & $8.33(2)$ & $10.10(7)$ & $55.6(3)$ \\
\hline NKJ & $24.3(9)$ & $4.90(3)$ & $5.08(9)$ & $1.70(7)$ & $0.44(9)$ & $4.22(1)$ & $4.75(7)$ & $7.5(6)$ & $55.7(6)$ & $7.86(7)$ & $9.36(10)$ & $53.6(6)$ \\
\hline APJ & $28.5(8)$ & $4.68(4)$ & $6.11(8)$ & $1.64(8)$ & $0.43(10)$ & $4.12(4)$ & $4.98(2)$ & $7.8(2)$ & $51.4(10)$ & $8.42(1)$ & $10.24(5)$ & $50.6(9)$ \\
\hline BLK & $14.2(12)$ & 3.27 (12) & $4.41(10)$ & 0.67 & $0.24(12)$ & 3.41 (11) & $4.97(3)$ & $7.1(11)$ & 37.5 (12) & $7.36(11)$ & $9.35(11)$ & 37.5 (12) \\
\hline KTK & $14.8(11)$ & $3.59(11)$ & 4.27 (11) & $1.62(10)$ & $0.56(7)$ & $3.58(9)$ & 4.05 (12) & $6.7(12)$ & $56.3(4)$ & $7.80(8)$ & 9.29 (12) & $54.9(4)$ \\
\hline PGC & $30.5(7)$ & $4.37(10)$ & $7.13(5)$ & $1.61(11)$ & $0.49(8)$ & $3.42(10)$ & $4.38(10)$ & $7.5(7)$ & $54.3(8)$ & $7.56(10)$ & $10.37(2)$ & $50.0(10)$ \\
\hline PKC & $34.3(3)$ & $4.64(5)$ & $7.46(4)$ & $1,90(6)$ & $0.58(6)$ & $3.67(8)$ & $4.77(6)$ & $7.8(3)$ & $65.7(3)$ & $7.71(9)$ & $10.19(6)$ & $63.8(2)$ \\
\hline BHS & $31.7(6)$ & $4.38(9)$ & $7.09(6)$ & $1,93(5)$ & $0.62(4)$ & $3.68(7)$ & $4.77(5)$ & 7.7 (4) & $74.4(1)$ & $8.08(3)$ & $10.25(4)$ & $70.0(1)$ \\
\hline KKP & $39.0(1)$ & $5.50(1)$ & $7.46(3)$ & $3.21(1)$ & $0.86(2)$ & $3.75(6)$ & $5.26(1)$ & $8.3(1)$ & 40.0 (11) & $7.97(5)$ & $11.86(1)$ & $40.0(11)$ \\
\hline $\begin{array}{l}\text { Provenance } \\
\text { range }\end{array}$ & $9.1-46.1$ & $2.51-6.48$ & $2.6-10.9$ & $0.32-5.86$ & $0.14-3.80$ & $0.34-7.01$ & $2.8-5.3$ & $4.0-7.6$ & $30-90$ & $5.1-10.2$ & $6.7-15.1$ & $10-75$ \\
\hline $\begin{array}{l}\text { SD for } \\
\text { provenance }\end{array}$ & 9.44 & 0.85 & 1.79 & 0.98 & 0.36 & 1.29 & 0.54 & 0.74 & 13.0 & 2.25 & 3.38 & 12.4 \\
\hline Family range & $3.5-55.5$ & $1.50-9.91$ & $1.1-15.4$ & $0.12-6.35$ & $0.04-3.90$ & $0.29-9.96$ & $1.0-9.6$ & $1.0-14.0$ & $25-100$ & $2.6-15.0$ & $1.1-31.3$ & $20-95$ \\
\hline SD for family & 10.49 & 1.14 & 2.26 & 0.94 & 0.35 & 1.12 & 1.51 & 2.14 & 13.0 & 1.04 & 1.42 & 12.5 \\
\hline Mean & 30.47 & 4.56 & 6.74 & 1.88 & 0.54 & 3.81 & 4.70 & 7.5 & 52.8 & 7.95 & 10.12 & 52.82 \\
\hline $\mathrm{CV}(\%)$ & 17.98 & 27.78 & 14.487 & 18.34 & 22.72 & 21.02 & 7.30 & 6.32 & - & 5.01 & 1.58 & - \\
\hline
\end{tabular}

Note: RPS: Rimbo Panti Nature Reverse, Pasaman, West Sumatra; KRS: Kampar, Riau, Sumatra; OKS: Ogan Komering Ilir, South Sumatra; GSJ: Garut Selatan, West Java; NKJ: Nusa Kambangan Nature Reverse, Central Java; APJ: Alas Purwo National Park, East Java; BLB: Batu Licin, Tanah Bumbu, South Kalimantan; KTB: Kapuas Tengah, Central Kalimantan; PGC: Parangloe, Gowa, South Sulawesi; PKC: Pomalaa, Kolaka, Southeast Sulawesi; BHS: Batu Hijau, Sumbawa, West Nusa Tenggara; KKP: Kuala Kencana, Mimika, Papua

Table 4. Components of variance and relative contribution (number in parentheses) of replications $\left(\sigma^{2} \mathrm{R}\right)$, provenances $\left(\sigma^{2} \mathrm{P}\right)$, interaction between replications and provenances $\left(\sigma^{2} \mathrm{RP}\right)$, families within provenances $\left(\sigma^{2} \mathrm{~F}(\mathrm{P})\right)$, interaction between replications and families $\left(\sigma^{2} \mathrm{RF}\right.$ $(\mathrm{P})$ ), and individual within families $\left(\sigma^{2} \mathrm{e}\right)$ of provenance-progeny tests at nursery, 2 years and 4 years after planting

\begin{tabular}{|c|c|c|c|c|c|c|c|c|c|c|}
\hline \multirow[b]{2}{*}{$\begin{array}{l}\text { Components } \\
\text { of variance }\end{array}$} & \multicolumn{6}{|c|}{ Nursery } & \multicolumn{2}{|c|}{2 years after planting } & \multicolumn{2}{|c|}{4 years after planting } \\
\hline & $\begin{array}{c}\text { Seedling } \\
\text { height } \\
(\mathrm{cm})\end{array}$ & $\begin{array}{c}\text { Collar } \\
\text { diameter } \\
(\mathrm{mm})\end{array}$ & $\begin{array}{c}\text { Sturdiness } \\
\text { quotient }\end{array}$ & $\begin{array}{l}\text { Shoot dry } \\
\text { weight (g) }\end{array}$ & $\begin{array}{l}\text { Root dry } \\
\text { weight (g) }\end{array}$ & $\begin{array}{c}\text { Shoot } \\
\text { root ratio }\end{array}$ & $\begin{array}{c}\text { Tree height } \\
\text { (m) }\end{array}$ & $\begin{array}{c}\text { Tree } \\
\text { diameter } \\
(\mathrm{cm})\end{array}$ & $\begin{array}{c}\text { Tree height } \\
\text { (m) }\end{array}$ & $\begin{array}{c}\text { Tree } \\
\text { diameter } \\
(\mathbf{c m})\end{array}$ \\
\hline \multirow[t]{2}{*}{$\sigma^{2} \mathrm{R}$} & 0.170 & 0.081 & 0.024 & 0.0103 & 0.0009 & 0.0066 & 0.355 & 0.560 & 1.496 & 2.168 \\
\hline & $(0.13)$ & $(3.35)$ & $(0.49)$ & $(1.03)$ & $(0.66)$ & $(0.38)$ & $(0.11 \%)$ & $(8.58 \%)$ & $(24.95 \%)$ & $(16.78 \%)$ \\
\hline \multirow[t]{2}{*}{$\sigma^{2} \mathrm{P}$} & 23.084 & 0.006 & 0.900 & 0.1300 & 0.0101 & 0.0737 & 0.013 & 0.019 & 0.010 & 0.005 \\
\hline & $(18.76)$ & $(0.24)$ & $(18.66)$ & $(13.07)$ & $(7.41)$ & $(4.33)$ & $(0.40 \%)$ & $(0.29 \%)$ & $(0.17 \%)$ & $(0.03 \%)$ \\
\hline \multirow[t]{2}{*}{$\sigma^{2} \mathrm{RP}$} & 0.032 & 0.651 & 0.006 & 0.0053 & 0.0021 & 0.0059 & 0.136 & 0.025 & 0.113 & 0.008 \\
\hline & $(0.02)$ & $(26.97)$ & $(0.12)$ & $(0.53)$ & (1.54) & $(0.34)$ & $(4.15 \%)$ & $(0.39 \%)$ & $(1.87 \%)$ & $(0.06 \%)$ \\
\hline \multirow[t]{2}{*}{$\sigma^{2} \mathrm{~F}(\mathrm{P})$} & 66.574 & 0.005 & 2.108 & 0.5273 & 0.0447 & 0.4085 & 0.304 & 0.510 & 0.028 & 0.001 \\
\hline & $(54.11)$ & $(0.21)$ & $(43.72)$ & $(53.02)$ & $(32.81)$ & $(24.01)$ & $(9.30 \%)$ & $(7.90 \%)$ & $(0.46 \%)$ & $(0.008 \%)$ \\
\hline \multirow[t]{2}{*}{$\sigma^{2} \mathrm{RF}(\mathrm{P})$} & 2.826 & 0.046 & 0.056 & 0.2025 & 0.0629 & 0.5658 & 1.080 & 1.300 & 2.360 & 2.434 \\
\hline & $(2.29)$ & (1.90) & (1.16) & $(20.36)$ & (46.18) & (33.26) & $(40.79 \%)$ & $(20.78 \%)$ & $(39.34 \%)$ & $(18.83 \%)$ \\
\hline \multirow[t]{2}{*}{$\sigma_{\mathrm{e}}^{2}$} & 30.330 & 1.624 & 1.727 & 0.1191 & 0.0155 & 0.6402 & 1.383 & 4.132 & 1.991 & 8.303 \\
\hline & $(24.65)$ & $(67.30)$ & $(35.82)$ & (11.97) & (11.38) & $(37.64)$ & $(45.28 \%)$ & $(62.06 \%)$ & $(33.19 \%)$ & $(64.26 \%)$ \\
\hline
\end{tabular}

The higher values toward variation among families within provenance in relation to provenances suggested that white jabon in each provenance had broad distribution in large population size. The population size and distribution range have been identified as major correlates of within-population genetic diversity in tropical tree species, while restricted populations showed significantly less variation than those with a broader distribution (Loveless 1992), while genetic variation varies directly with population size (Travis et al. 1996; Moluvi et al.
1999). The seed exploration in this study was carried out in secondary forest and white jabon is a pioneer species that generally dominates the natural secondary forest structure (Orwa et al. 2009; Wahyuni and Kafiar 2017; Aththorick et al. 2018). According to Lowe et al. (2018), pioneer species generally had higher variation in genetic diversity than range-restricted species. Study based on AFLP loci using the same population samples of white jabon showed that the genetic diversity within and between the populations are relatively high (Sudrajat et al. 2015). Species with 
larger range sizes should also, at least in part, have greater dispersal capacity or maintain larger effective population sizes, and both would result in reduced effects of random genetic drift on genetic diversity (Lowe et al. 2018). In other hand, for some range-restricted species like Dipterocarpus littoralis in secondary forest in Nusa Kambangan (Dwiyanti et al. 2014) demonstrated low genetic diversity within population, nevertheless Fernández-Mazuecos et al. (2014) found that most of the narrowly distributed species on European islands showed moderate or high levels of genetic diversity depended on multiple factors, particularly the evolutionary history of the populations (Forest et al. 2017).

\section{Correlation among growth parameters in the nursery and in the field}

Most of the seedling parameters were significantly correlated with the others, except for the correlation between seedling collar diameter with sturdiness quotient and between shoot dry weight with shoot root ratio (Table 5). The strongest correlation was between seedling height and sturdiness quotient $\left(r^{2}=0.803\right)$, followed by shoot and root dry weights $\left(r^{2}=0.763\right)$ and seedling height and seedling collar diameter $\left(r^{2}=0.631\right)$.

Using family means across time in the nursery and in the field, most of the seedling parameters were not significantly correlated with plant growth at 2 years, except for correlation of collar diameter with plant survival $\left(\mathrm{r}^{2}=\right.$ $0.195)$, and shoot dry weight with plant diameter $\left(r^{2}=\right.$ $0.255)$ and height $\left(r^{2}=0.252\right)$ at 2 years. The significant correlation also was showed by seedling root dry weight with plant survival at 4 years $\left(r^{2}=0.214\right)$ (Table 6). Most of the correlations among family and provenance means were positive and consistent with this expectation: all nursery growth variables, except seedling height, sturdiness quotient, and shoot-root ratio, were and positively correlated with tree height and diameter at 2 years in the field. The weak negative correlations between family mean for seedling height was reported on a comparison of seedling in nursery and field growth of Prosopis africana (Weber et al. 2015).

Table 5. Correlation (Pearson) among growth parameters of white jabon seedlings in a provenance-progeny nursery test based on all seedlings in the test

\begin{tabular}{|c|c|c|c|c|c|}
\hline $\begin{array}{l}\text { Nursery growth } \\
\text { parameters }\end{array}$ & SH & SCD & SQ & SDW & RDW \\
\hline SCD & $0.631^{* *}$ & & & & \\
\hline SQ & $0.803^{* *}$ & 0.070 & & & \\
\hline SDW & $0.477^{* *}$ & $0.473^{* *}$ & $0.234^{*}$ & & \\
\hline RDW & $0.621^{* *}$ & $0.581^{* *}$ & $0.351^{* *}$ & $0.763^{* *}$ & \\
\hline SRR & $0.273^{* *}$ & 0.183 & $0.247^{*}$ & 0.157 & $-0.361^{* * *}$ \\
\hline
\end{tabular}

Note: SH: seedling height, SCD: seedling collar diameter, SQ: sturdiness quotient, SDW: shoot dry weight, RDW: root dry weight, SRR: shoot root ratio, *: significant at $P<0.05, * *$ : significant at $P>0.01$

Table 6. Correlation (Pearson) between growth parameters of white jabon in a provenance-progeny nursery test and a field test at 2 and 4 years calculated using family means and provenance means

\begin{tabular}{|c|c|c|c|c|c|c|}
\hline \multirow{2}{*}{$\begin{array}{l}\text { Field growth } \\
\text { parameters }\end{array}$} & \multicolumn{6}{|c|}{ Nursery growth parameters } \\
\hline & SH & SCD & SQ & SDW & RDW & SRR \\
\hline \multicolumn{7}{|c|}{ Correlation between family means } \\
\hline $\mathrm{H} 2$ & -0.120 & 0.057 & -0.100 & $0.255^{* *}$ & 0.120 & -0.139 \\
\hline D2 & -0.115 & 0.124 & -0.053 & $0.252^{* *}$ & 0.048 & -0.187 \\
\hline $\mathrm{S} 2$ & -0.015 & $0.195^{*}$ & -0.169 & 0.132 & 0.008 & 0.092 \\
\hline $\mathrm{H} 4$ & 0.038 & 0.007 & 0.064 & 0.022 & 0.097 & 0.050 \\
\hline D4 & 0.131 & 0.025 & 0.167 & 0.029 & 0.053 & 0.051 \\
\hline S4 & 0.164 & 0.109 & 0.115 & 0.128 & $0.214^{*}$ & 0.057 \\
\hline \multicolumn{7}{|c|}{ Correlation between provenance means } \\
\hline $\mathrm{H} 2$ & -0.497 & 0.498 & $-0.595^{*}$ & 0.542 & 0.524 & -0.543 \\
\hline D2 & -0.451 & 0.536 & -0.506 & 0.513 & 0.515 & -0.524 \\
\hline $\mathrm{S} 2$ & -0.479 & 0.409 & -0.359 & $0.969^{* *}$ & $0.986^{* *}$ & $-0.976^{* *}$ \\
\hline $\mathrm{H} 4$ & 0.429 & 0.094 & 0.508 & 0.143 & 0.082 & -0.116 \\
\hline D4 & 0.536 & 0.480 & 0.476 & $0.819^{* *}$ & $0.823^{* *}$ & 0.522 \\
\hline S4 & 0.018 & 0.121 & 0.042 & 0.547 & $0.621^{*}$ & -0.573 \\
\hline
\end{tabular}

Note: SH: seedling height, SCD: seedling collar diameter, SQ: sturdiness quotient, SDW: shoot dry weight, RDW: root dry weight, SRR: shoot-root ratio, H2: plant height at 2 years, D2: stem diameter at 2 years, S2: survival at 2 years, H4: plant height at 4 years, D4: stem diameter at 4 years, S4: survival at 4 years, *: significant at $P<0.05$, **: significant at $P>0.01$. 
Table 7. Correlation (Pearson) between growth parameters of white jabon in the nursery and the field tests with some geo-climate variables

\begin{tabular}{lcccccccccccc}
\hline & SH & SCD & SQ & SDW & RDW & SRR & H2 & \multicolumn{1}{c}{ D2 } & S2 & H4 & D4 & S4 \\
\hline Latitude & 0.341 & 0.208 & 0.399 & -0.024 & -0.052 & 0.013 & -0.134 & -0.163 & -0.028 & 0.495 & 0.127 & -0.069 \\
Longitude & 0.347 & 0.115 & 0.393 & $0.702^{*}$ & $0.695^{*}$ & $0.727^{* *}$ & -0.306 & -0.182 & $-0.756^{* *}$ & -0.027 & $0.714^{* * *}$ & -0.527 \\
Altitude & 0.134 & 0.037 & 0.140 & -0.044 & -0.034 & -0.077 & -0.092 & -0.076 & 0.114 & 0.123 & 0.032 & 0.253 \\
Precipitation & -0.292 & -0.096 & -0.366 & 0.081 & 0.102 & 0.042 & -0.049 & -0.092 & -0.001 & -0.169 & -0.151 & -0.027 \\
Temperature & -0.513 & -0.468 & -0.442 & -0.373 & -0.364 & -0.373 & 0.424 & 0.452 & 0.361 & -0.334 & -0.352 & 0.048 \\
\hline
\end{tabular}

Note: see Table 6 for seedling parameters information, *: significant at $P<0.05$, **: significant at $P>0.01$

On the provenance level, seedling sturdiness quotient was negatively correlated with plant height at 2 years $\left(r^{2}=\right.$ -0.595). Shoot dry weight was positively correlated with plant survival at 2 years $\left(r^{2}=0.255\right)$ and stem diameter at 4 years $\left(r^{2}=0.252\right)$. The same correlation result also was revealed by root dry weight that was significantly correlated with plant survival at 2 years $\left(r^{2}=0.986\right)$ and 4 years $\left(r^{2}=0.621\right)$, and stem diameter at 4 years $\left(r^{2}=\right.$ 0.823 ). A negatively significant correlation was showed by seedling shoot-root ratio and plant survival at 2 years $\left(\mathrm{r}^{2}=-\right.$ 0.976). Generally, the family or provenance selections based on growth (especially for height and diameter) in the nursery may not be very effective because heritability of most growth variables is likely to be low. This suggestion was similar to the study on P. africana (Weber et al. 2015) and B. aegyptiaca (Weber et al. 2018).

\section{Correlations of growth parameters in the nursery and field with geo-climate variables}

Most of the parameters in the seedling growth in the nursery and plant performance were not significantly correlated with geo-climate variables, expect for longitude that provided significant correlation with shoot dry weight $\left(r^{2}=0.702\right)$, root dry weight $\left(r^{2}=0.695\right)$, shoot-root ratio (0.727), plant survival at 2 years $\left(r^{2}=-0.756\right)$, and stem diameter at 4 years $\left(r^{2}=0.714\right)$ (Table 7).

In this study, the longitudinal line in shoot dry weight, root dry weight, and shoot-root ratio indicated that the jabon seeding parameters in natural populations might have greater in humid (higher precipitation) than in more drier locations. Study of variation in seed weight are consistent with this hypothesis that jabon trees from drier natural populations in eastern Indonesia showed the higher seed weight increased from the more humid western populations to the drier northern locations (Sudrajat 2016), which could facilitate faster shoot and deeper root growth of seedlings in the drier locations (Abasse et al. 2011). Shoot-root ratio measures the balance between the transpiration area (shoot) and the water absorbing area (root) of the seedlings (Haase 2008) and in this study, the higher shoot-root ratio caused the low survival at 2 years. The planting site in this study is a marginal soil with low levels of $\mathrm{N}, \mathrm{P}, \mathrm{K}$ and C-organic with $\mathrm{pH} 4.2$ (Sudrajat et al. 2016) so the higher shoot-root ratio of tree seedling was not suitable creating a seriously damaged when exposed to wind and drought. The sturdiness quotient should closely parallel diameter in predicting survival and growth in the field (Surata 2012; Budiman et al. 2015).
In conclusion, genetic variation in white jabon was found to be higher among families within provenances than the variation among provenances for all parameters indicating the family effect had the highest contribution on the growth and survival variation. White jabon in each observed provenance relatively had broad distribution in large population size, identified as major correlates of within-population genetic diversity. Most of the seedling parameters based on family mean were significantly correlated with the others, but most of the seedling parameters were not significantly correlated with plant growth at the field, except for correlation of collar diameter with plant survival $\left(r^{2}=195\right)$, shoot dry weight with plant diameter $\left(r^{2}=0.255\right)$ and height $\left(r^{2}=0.252\right)$ at 2 years, and root dry weight with plant survival at 4 years $\left(r^{2}=0.214\right)$. Most of the parameters in seedling growth in the nursery and plant performance were not significantly correlated with geo-climate variables, except for longitude. The longitudinal cline in shoot dry weight, root dry weight, and shoot-root ratio indicated that the jabon seeding parameters in natural populations might have greater in humid (higher precipitation) than in drier locations. This was likely to suggest that the family or provenance selections based on growth, especially based on seedling height and diameter in the nursery might not be very effective because heritability of most growth variables is likely to be low.

\section{ACKNOWLEDGEMENTS}

We thank the Seameo Biotrop (Bogor, West Java), PT. Arutmin Indonesia (Batu Licin, South Kalimantan), PT. Dasa Intiga (Kapuas, Central Kalimantan), PT. Newmont Indonesia al (Batu Hijau, Sumbawa) for accommodations support during genetic material collection. We were grateful to the authorities of Forest Tree Seed Technology Research and Development Center for financing the establishment of provenance-progeny test at Parung Panjang, Bogor, West Java, Indonesia.

\section{REFERENCES}

Abasse T, Weber JC, Katkore B, Boureima M, Larwanou M, Kalinganire A. 2011. Morphological variation in Balanites aegyptiaca fruits and seeds within and among parkland agroforests in eastern Niger. Agrofor Syst 81: 57-66 DOI 10.1007/s10457-010-9323-x. 
Acharyya S, Rathore DS, Kumar HKS, Panda N. 2011. Screening of Anthocephalus cadamba (Roxb.) Miq. root for antimicrobial and anthelmintic activities. Intl J Res Pharm Biomed Sci 2 (1): 297-300.

Aththorick TA, Pasaribu N, Eyckman E. 2018. Stand structure and carbon stock of tree vegetation in Deleng Macik Taman Hutan Raya Bukit Barisan Karo District, North Sumatra, Indonesia. IOP Conf. Series: J Phys: Conf. Series 1116 (2018) 052009. Pp 1-9.

Bayala J, Sanon X, Bazie P, Sanou J, Roupsard O, Jourdan C, Raebild A Kelly B, Okullo JBL, Thiam M, Yidana J. 2017. Relationships between climate at origin and seedling traits in eight Panafrican provenances of Vitellaria paradoxa C.F. Gaertn under imposed drought stress. Agroforestry Syst 92 (6): 1455-1467. DOI: 10.1007/s1045 7-017-0091-8

Bezzalla A, Boudjabi S, Chenchouni H. 2017. Seedlings of argan (Argania spinosa) from different geographical provenances reveal variable morphological growth responses to progressive drought stress under nursery conditions. Agrofor Syst 92 (5): 1201-1211. DOI: $10.1007 / \mathrm{s} 1045$ 7-016-0057-2

Bouda ZHN, Bayala J, Jensen JS, Markussen B, Raebild A. 2015 Reactions of Adansonia digitata $\mathrm{L}$. provenances to long-term stress at seedling stage. Agroforestry Syst 89 (1): 113-123. DOI: 10.1007/s1045 7-014-9746-x.

Budiman B, Sudrajat DJ, Lee DK, Kim YS. 2015. Effect of initia morphology on-field performance in white jabon seedlings at Bogor, Indonesia. For Sci Tech 11 (4): 206-211.

Cuni-Sanchez A, De Smedt S, Haq N, Samson R. 2011. Variation in baobab seedling morphology and its implications for selecting superior planting material. Sci Hortic 130: 109-117. DOI: 10.1016/j.scien ta.2011.06.021

Dwiyanti FG, Harada K, Siregar IZ, Kamiya K. 2014. Population genetics of the critically endangered species Dipterocarpus littoralis Blume (Dipterocarpaceae) endemic in Nusa Kambangan island, Indonesia Biotropia 21 (1): 1-12.

Falconer DS, Mackay TFC. 1996. Introduction to Quantitative Genetics. 4th Edition. Longman Inc. New York.

Fernández-Mazuecos M, Jiménez-Mejías $\mathrm{P}$, Rotllan-Puig X, Vargas $\mathrm{P}$ 2014. Narrow endemics to Mediterranean islands: moderate genetic diversity but narrow climatic niche of the ancient, critically endangered Naufraga (Apiaceae). Perspect Plant Ecol Evol Syst 16: 190-202.

Forest A, Escudero M, Heuertz M, Wilson Y, Cano E, Vargas P. 2017. Testing the hypothesis of low genetic diversity and population structure in narrow endemic species: The endangered Antirrhinum charidemi (Plantaginaceae). Bot J Linn Soc 183: 260-270.

Haase DL. 2008. Understanding forest seedling quality: Measurements and interpretation. Tree Plant Notes 52 (2): 24-30.

Irawan US, Purwanto E. 2014. White jabon (Anthocephalus cadamba) and red jabon (Anthocephalus macrophyllus) for community land rehabilitation: Improving local propagation efforts. Agricul Sci 2 (3): 36-45.

Jacobs DF, Oliet JA, Aronson J et al. 2015. Restoring forests: what constitutes success in the 21st century? New For 46: 601-614. DOI: 10.1007/s1105 6-015-9513-5

Kallio MH, Krisnawati H, Rohadi D, Kanninen M. 2011. Mahogany and kadam planting farmers in South Kalimantan: The link between silvicultural activity and stand quality. Small-scale For 10: 115-132.

Korbo A, Sanou H, Raebild A, Jensen JS, Hansen JK, Kjaer ED. 2012 Comparison of East and West African populations of baobab (Adansonia digitata L.). Agrofor Syst 85: 505-518. DOI: 10.1007/s1045 7-011-9464-6.

Ky-Dembele C, Tigabu M, Bayala J, Odén PC. 2014. Inter- and intraspecific provenances variations in seed size and seedling characteristics of Khaya senegalensis A. Juss in Burkina Faso. Agrofor Syst 88: 311-320. DOI: 10.1007/s1045 7-014-9684-7.

Lamprecht H. 1989. Silviculture in the Tropics; Tropical Forest Ecosystems and their Tree Species - Possibilities and Methods for their Long-term Utilization. Deutsche Gesellschaft fur Technische Zusammenarbeit (GTZ). Eschborn.

Longauer R. 2001. Genetic variation of European silver fir (Abies alba Mill.) in the Western Carpathians. J For Sci 47: 429-438.
Loveless, M.D. 1992. Isozyme variation in tropical trees: patterns of genetic organization. New For 6: 67-94.

Lowe AJ, Breed MF, Caron H et al. 2018. Standardized genetic diversitylife history correlates for improved genetic resource management of Neotropical trees. Divers Distrib 24: 730-741.

Mihai G, Mirancea I. 2016. Age trends in genetic parameters for growth and quality traits in Abies alba. iForest 9: 954-959. DOI: 10.3832/ifor1766-009.

Mishra RP, Siddique L. 2011. Antibacterial properties of Anthocephalus cadamba fruits. Asian J Plant Sci Res 1 (2): 1-7.

Moluvi GM, Sprent JI, Soranzo N et al. 1999. Amplified fragment length polymorphism (AFLP) analysis of genetic variation in Moringa oleifera Lam. Mol Ecol 8: 463-470.

Morgenstern EK. 1996. Geographic Variation in Forest Trees - Genetic Basis and Application of Knowledge in Silviculture. University of British Columbia Press, Vancouver.

Orwa C, Mutua A, Kindt R, Jamnadass R, Anthony S. 2009. Agroforestry tree database: a tree reference and selection guide version 4.0. http: //www.worldagroforestry.org/treedb2/AFTPDFS/Anthocephaluscada mba.pdf.

Sebbenn AM, Pontinha AAS, Kageyama PY. 2003. Genetic variation in provenance-progeny test of Araucaria angustifolia (Bert.) O. Ktze. in Sao Paulo, Brazil. Silvae Genet 52: 5-6.

Soerianegara I, Lemmens RHMJ. 1993. Plant Resources of South-East Asia 5 (1): Timber Trees: Major Commercial Timbers. Pudoc Scientific Publishers, Wageningen.

Sudrajat DJ, Siregar IZ, Khumaida N, Siregar UJ, Mansur I. 2015. Genetic diversity of white jabon (Anthocephalus cadamba Miq.) based on AFLP markers. Asia Pac J Mol Biol Biotech 2 (3): 224-231.

Sudrajat DJ. 2016. Genetic variation of fruit, seed and seedling characteristics among 11 populations of white jabon in Indonesia. For Sci Tech 12 (1): 9-15.

Sudrajat DJ, Nurhasybi, Siregar IZ, Khumaida N, Siregar UJ, Mansur I. 2016. Intraspecific variation of early growth of Neolamarckia cadamba provenance-progeny test in West Java, Indonesia. Biotropia 23 (1): $10-20$

Surata IK. 2012. The growth of sandalwood seedlings at various container sizes in semi-arid region. Wallacea 1 (1): 13-25. [Indonesian].

Travis, S.E., Maschenski, J. Keim P. 1996. An analysis of genetic variation in Astragalus cremnophylax var. Cremnophylax, a critically endangered plant, using AFLP markers. Mol Ecol 5: 735-745.

Trubat R, Cortina J, Vilagrosa A. 2010. Nursery fertilization affects seedling traits but not field performance in Quercus suber L. J Arid Environ 74 (4): 491-497. DOI: 10.1016/j.jaridenv.2009.10.007

Villar-Salvador P, Valladares F, Domínguez-Lerena S, et al. 2008. Functional traits related to seedling performance in the Mediterranean leguminous shrub Retama sphaerocarpa: Insights from a provenance, fertilization, and rhizobial inoculation study. Environ Exp Bot 64 (2): 145-154. DOI: 10.1016/j.envexpbot.2008.04.005.

Wahyudi. 2012. Growth and yield analysis of jabon (Anthocephallus cadamba) plantation. J Parennial 8 (1): 19-24. [Indonesian].

Wahyuni NI, Kafiar Y. 2017. Species composition and structure of secondary forest at Nunuka, Nort Bolaang Mongondow. Jurnal Wasian 4 (1): 27-36. [Indonesian].

Weber JC, Montes CS, Soumana I, Diallo BO, Abasse T, Larwanou M, Bationo AB. 2018. Genetic and geographic variation in growth of Balanites aegyptiaca in Niger: comparing results from provenance/ progeny tests in the nursery and field. New For. DOI: 10.1007/s11056-018-9686-9

Weber JC, Montes CS, Kalinganire A, Abasse T, Larwanou M. 2015. Genetic variation and clines in growth and survival of Prosopis africana from Burkina Faso and Niger: comparing results and conclusions from a nursery test and a long-term field test in Niger. Euphytica 205: 809-821. DOI: 10.1007/s1068 1-015-1413-4.

Yang H, Liu T, Liu C, et al. 2013. Genetic parameters and efficiency of early selection for half rotation-aged growth and form traits in Pinus taeda in China. Silvae Genet 62 (6): 277-284.

Zida D, Tigabu M, Sawadogo L, Oden PC. 2008. Initial seedling morphological characteristics and field performance of two Sudanian savanna species in relation to nursery production period and watering regimes. For Ecol Manag 255: 2151-2162. 